DOI https://doi.org/10.30525/978-9934-26-007-0-1

\title{
INFORMATION LAW DEVELOPMENT IN UKRAINE: THE ROLE OF SCIENTIFIC LAW SCHOOLS
}

\author{
Aristova I. V., Tkachenko V. V.
}

\section{INTRODUCTION}

According to the Basic Principles of the Development of Information Society in Ukraine ${ }^{1}$, the main task is to provide everyone with assistance, based on the widespread use of information and communication technologies (hereinafter referred to as the ICT), in generating, using and exchanging information and knowledge on the basis of the goals and principles of the United Nations proclaimed at the World Summits on Information Society. One of the expected worthwhile results from the implementation of the Basic Principles should be an appropriate level of legal regulation of public relations that arise in the context of the information society built on knowledge ${ }^{2}$. Based on the fact that an indispensable prerequisite for the transition from the information society to the knowledge society is a universal access to knowledge (including legal one), and a sufficient condition is the joint utilization of knowledge ${ }^{3}$ (including legal one), it should be noted that the so-called "new ethics of knowledge" (including legal one) should be formed in the knowledge society ${ }^{4}$.

In this regard, the task of creating effective tools for introducing a new ethics of legal knowledge is very urgent that will contribute, in turn, to obtaining an expected worthwhile result - appropriate level of law and order in the knowledge society. In our opinion, one of these tools should be the formation of scientific law schools. By the way, it is known that ${ }^{5}$ the creation of scientific law schools is defined as one of the directions of further development of legal education in Ukraine. Thus, the establishment of scientific schools, in particular scientific schools of information law (which in the countries of the European Union is considered to be the legal foundation of knowledge society) becomes an urgent task, which also determines the relevance of the topic of this paper.

The goal of the article is as follows: 1) to determine the role and place of scientific schools of information law in the creation of legal knowledge in the field

\footnotetext{
${ }^{1}$ Про Основні засади розвитку інформаційного суспільства в Україні на 2007-2015 роки : Закон України від 09.01.2007. URL https://goo.gl/oPp05P (дата звернення: 18.10.2020).

${ }^{2}$ К обществам знаний: Всемирный доклад ЮНЕСКО. Париж : Изд-во ЮНЕСКО, 2005. 211 с.

${ }^{3}$ Там само.

${ }^{4}$ Там само.

5 Вдосконалення вищої правничої (юридичної) освіти для фахової підготовки правника відповідно до європейських стандартів вищої освіти та правничої професії. Проект Концепції від 14.09.2016. URL : https://goo.gl/BBB1OL (дата звернення: 18.10.2020).
} 
of information law required to ensure law and order in the knowledge society; 2) to determine the fundamental principles of creating a scientific school in the field of information law (I.V. Aristova under the guidance of one of the authors of the article); 3) to find out the main directions of a research program of the scientific school; 4) to highlight the genesis of scientific results of the school in the form of concepts, theoretical models, concepts as legal knowledge in the field of information law required for the development of knowledge society in Ukraine.

\section{Fundamental principles of creating a scientific school in the field of information law. Research program of the scientific school}

We consider it appropriate in the first part of the paper to focus on the arrangements for achieving the first three components of the goal of this study.

In the first instance, we believe it necessary to emphasize that all the scientific results of the authors of this paper have been obtained under the influence of thorough legal knowledge of well-known Ukrainian and foreign scientists, such as V.B. Averianov, O.M. Bandurka, Yu.P. Bytiak, V.K. Kolpakov, I.L. Bachylo, Yu.O. Tykhomyrov, R.A. Kaliuzhnyi, M.M. Tyshchenko, O.F. Skakun and others. It is these scientists, who have contributed both to the development of authors as specialists in the field of information law and to the formation of a scientific school of information law under the guidance of one of the authors of this paper. It is beyond argument that legal knowledge in the field of information law is the result of joint search and discussion of our colleagues and like-minded fellows such as A.O. Baranov, K.I. Beliakov, V.M. Bryzhko, A.I. Marushchak, B.A. Kormych, A.M. Novytskyi, V.H. Pylypchuk, V.S. Tsymbaliuk and other respected scientists in the relevant scientific community.

At the same time, in our opinion, the development of systemic legal knowledge in the field of information law requires the formation of scientific schools that interact with each other to ensure law and order, in particular, in the information field. It is common practice to understand the concept of scientific school as a form of arranging a composite scientific work of employees of a scientific institution or educational institution under the guidance of a leader(s) of the school, usually from among well-known scientists ${ }^{6}$. From our point of view, a scientific school as an informal creative team of researchers, who are united by a common program and style of research work, and act under the guidance of a recognized leader, should not be limited to the "walls" of a particular institution. We believe that it is the main idea that should become a system-forming factor in

\footnotetext{
${ }^{6}$ Пилипчук В.Г., Фурашев В.М. Трансформація Центру правової інформатики в Науково-дослідний інститут інформатики і права: становлення, здобутки, пріоритети (2011-205 р.p.): науково-інформаційний огляд. За інформаційно-технічної підтримки В.М. Брижка, В.М. Поперечнюк, О.Г. Родзієвської. Київ : ТОВ «ПанТот», 2016. 106 с. С. 31.
} 
the establishment and operation of a scientific school. In our opinion, the implementation of the main functions of a scientific school (production of scientific knowledge; dissemination of scientific knowledge; training of intellectually gifted specialists ${ }^{7}$ ) in the context of development of the information society based on knowledge should be carried out taking into account the new ethics of knowledge societies - "unity in diversity".

We believe that in case of the formation of scientific law schools, the introduction of a new ethics of the knowledge society should take place as follows. Each branch ("diversity") of the national legal system, producing a variety of legal knowledge, should proceed not from branch (local) goals, but from a common goal ("unity"), which involves ensuring proper law and order in the knowledge-based society. At the same time, the integrity ("unity") of the national law system should be ensured by the interaction (mutual perception) of branches of law that (although they have in their arsenal a variety of legal remedies and arrangements ("diversity")) are harmonized and regulated due to a common goal that is to ensure law and order.

We believe that it is advisable to disseminate the concept of a balanced combination of structural and, to a certain extent, "structureless" forms of organizing scientific schools. In our opinion, a typical example of the implementation of the above concept is the operation of the scientific school of information law under the leadership of I.V. Aristova, one of the authors of the article, whose research team works not only at the Faculty of Law (the Department of Administrative and Information Law) of Sumy National Agrarian University, but also in the Chief Scientific Expert Department of the Administrative Office of the Verkhovna Rada of Ukraine, the Supreme Court of Ukraine, the Secretariat of the Cabinet of Ministers of Ukraine, the Ministry of Internal Affairs of Ukraine, etc. At the same time, the proposed concept of the forms of organizing (structural and "structureless") a scientific school is also implemented in the Law and Informatics Research Institute (hereinafter referred to as the LIRI) of the National Academy of Legal Sciences of Ukraine. According to the Regulation on Scientific Schools of the Institute ${ }^{8}$, scientists of other scientific institutions and educational establishments of Ukraine and foreign countries may be involved in the composition of a scientific school by a decision of the Academic Council of the Institute (with consent). On a related note, the

\footnotetext{
7 Пилипчук В.Г., Фурашев В.М. Трансформація Центру правової інформатики в Науково-дослідний інститут інформатики і права: становлення, здобутки, пріоритети (2011-205 р.р.): науково-інформаційний огляд. За інформаційно-технічної підтримки В.М. Брижка, В.М. Поперечнюк, О.Г. Родзієвської. Київ : ТОВ «ПанТот», 2016. 106 с. С. 32.

${ }^{8}$ Положення про наукові школи Науково-дослідного інституту інформатики і права НАПрН України: протокол засідання Вченої ради від 9 грудня 2015 року № 8. URL : https://goo.gl/B1CmYU (дата звернення: 18.10.2020).
} 
authors of this article are also the members of the scientific school "Information Law" of the Law and Informatics Research Institute of the National Academy of Legal Sciences of Ukraine.

By virtue of the main provisions of the system approach, it can be argued that a corresponding system - LIRI, which should implement the function of "formation of scientific schools on information law" has been created, inter alia, for the implementation of one of the functions of the super-system (the Academy of Legal Sciences of Ukraine), which involves the "formation of scientific law schools". The implementation of this function may be carried out both in the structural and "structureless" forms of organization. In the case of structural form, we are talking about the creation of subsystems (based on the departments and laboratories of LIRI) that may form scientific schools in various areas of the science of information law. At the same time, individual scientists, who are involved in the formation of a scientific school of information law on the basis of LIRI, in turn, may also create appropriate subsystems (using the "structureless" form of organization), which, on the basis of a common idea, can turn into scientific schools in certain areas of the science of information law. We believe that it is the constructive use of provisions of the system approach that will contribute to the formation of scientific schools on information law, the development of which is focused on meeting the requirements of the Order of the Ministry of Education and Science of Ukraine "On Approval of the Provisional List and Description of Subject Areas on the Specialty 081. Law" dated December 28, 2018 No. $1477^{9}$.

Thus, the formation and development of the scientific school in the field of information law (under the guidance of the author of the article) is, on the one hand, an integral component (subsystem) of the system of scientific schools of information law. At the same time, this school produces relevant legal knowledge and exchanges it with representatives of other scientific schools. On the other hand, the scientific school, which one of the authors of this paper is in charge of, from the beginning of its establishment to the present day has a look of its own, based on the following fundamental principles: 1) methodological pluralism in jurisprudence; 2) systematic worldview; 3) consistency of legal science, which requires interaction of (actions that contribute to) branch legal sciences (including the science of information law) in order to ensure proper law and order in society; 4) provisions of the general theory of state and law is the foundation of any branch legal science (including the science of information law); 5) formation of the methodology of scientific research in the field of information law, which is

\footnotetext{
${ }^{9}$ Про затвердження примірного переліку та опису предметних напрямів досліджень в межах спеціальності 081 «Право» : Наказ МОН України від 28.12.2018 № 1477. URL : https://zakon.rada.gov.ua/ go/v1477729-18 (дата звернення: 19.10.2020).
} 
understood as the doctrine of the organization of scientific activity and scientific knowledge in the field of information law, including the subject (scientist, scholar), object, goal, methods of scientific activity; 6) the science of information law should take into account the information patterns and trends, which govern the evolution of the society's development, as well as the philosophical and methodological aspect of information that involves ensuring the "proactive" reflection of reality in self-regulatory systems, which is reflected in information processes and affects the essence of information relations; 7) reference point for determining the role and place of the science of information law in the general system of legal sciences should be the basic principles of developing the information society based on knowledge (knowledge society), namely: a) universal access to knowledge; b) joint utilization of knowledge; c) common participation in knowledge societies; d) actual enforcement of human rights; e) international essence of information law stemming from, among other things, the peculiarities of the formation of knowledge societies that provide for international cooperation. We believe that the above postulates of the scientific school may be considered as "common scientific views" and "shared research work", the mandatory existence of which is emphasized in the definition of the concept of scientific school.

In our opinion, special attention should be paid to the development of a unified research program of the scientific school, which, by the way, is called "Legal Foundations of the Information Society based on Knowledge and Information-Driven State" and conditioned by the need to implement a common idea. In other words, the research program has been formed based on the need to conduct scientific research not only in the field of information law, but also taking into account the interaction of information law with other branches of law (administrative, financial, environmental, agricultural, etc.) in the context of the development of the information society based on knowledge and the information-driven state in Ukraine. Taking into account the initial provisions of the system approach, the unity of the research program of the scientific school is ensured by defining a common goal, which is effectively achieved through the system form of organizing the research program. At the same time, depending on the classification criteria, it is possible to obtain different structural elements (directions) of the research program. For example, such criteria may include: 1) the guiding principles and foundations of the knowledge-based information society and information-driven state; 2) theory and practice, etc. The analysis of these classification criteria has made it possible to establish the feasibility of their combination, which leads to the following structure of a common research program. 
1. The theory of information law of Ukraine: scientific doctrine of information law in the conditions of the information society based on knowledge ${ }^{10}$; methodology of the science of information law ${ }^{11,12}$; conceptual framework (for example ${ }^{13,14,15}$ ); principles and functions of information law ${ }^{16}$; mechanism of legal regulation of information relations ${ }^{17}{ }^{18}$; theory of information legal relations ${ }^{19,20,21}$; rules of information law; forms of implementation of the rules of information law; legal means of information law; information and legal status of an individual and a legal entity ${ }^{22,23}$; information and legal status of government bodies and local self-government authorities ${ }^{24,25,26}$; subjects of information law and information

10 Арістова І.В. Наука «інформаційне право» на новому етапі розвитку інформаційного суспільства. Правова інформатика. 2011. № 1. С. 3-11.

${ }^{11}$ Арістова І.В. Становлення науки «інформаційне право»: питання методології. Ч. І. Публічне право. 2016 p. № 2. C. 245-250.

12 Арістова І.В. Становлення науки «інформаційне право»: питання методологіі. Ч. 2. Публічне право. 2016 p. № 3. С. 232-243.

${ }^{13}$ Свистович Р.С. Правове регулювання інформаційних відносин у сфері масової інформації : автореф. дис. ... канд. юрид. наук : 12.00.07. Київ, 2011. 20 с.

${ }^{14}$ Арістова І.В., Кузнецова М.Ю. Реалізація інформаційно-правового статусу органів виконавчої влади України в інформаційних правовідносинах : монографія / За заг. ред. І.В. Арістової. Київ : Видавничий центр НУБіП України, 2015. 250 с.

15 Арістова I.В., Чернадчук В.Д. Концепція інформаційних правовідносин: сутність та особливості використання у сфері банківської діяльності. URL : https:/goo.gl/6ZРуTf (дата звернення: 19.10.2020).

16 Арістова I.В., Ткаченко В.В. Інформаційне законодавство України: проблеми адаптації до міжнародних правових стандартів : монографія / За заг. ред. І.В. Арістової. Київ : Видавничий центр НУБіП України, 2015. 185 с.

${ }^{17}$ Свистович Р.С. Правове регулювання інформаційних відносин у сфері масової інформації : автореф. дис. ... канд. юрид. наук : 12.00.07. Київ, 2011. 20 с.

${ }^{18}$ Арістова І. В. М. Ю. Кузнецова Реалізація інформаційно-правового статусу органів виконавчої влади України в інформаційних правовідносинах: монографія / За заг. ред. І. В. Арістової. КИЇВ :Видавничий центр НУБіП України, 2015. 250 с.

${ }^{19}$ Арістова І.В., Кузнецова М.Ю. Реалізація інформаційно-правового статусу органів виконавчої влади України в інформаційних правовідносинах : монографія. Київ : Видавничий центр НУБіП України, 2015. $250 \mathrm{c.}$

20 Арістова I.В., Чернадчук В.Д. Концепція інформаційних правовідносин: сутність та особливості використання у сфері банківської діяльності. URL : https://goo.gl/6ZРуTf (дата звернення: 19.10.2020).

${ }^{21}$ Чернадчук Т. О. Актуальні питання інформаційних правовідносин у банківській сфері : монографія / За заг. ред. І.В. Арістової. Суми : Вид-во СНАУ, 2011. 162 с.

${ }_{22}$ Арістова І.В., Кузнецова М.Ю. Реалізація інформаційно-правового статусу органів виконавчої влади України в інформаційних правовідносинах : монографія / За заг. ред. І.В. Арістової. Київ : Видавничий центр НУБіП України, 2015. 250 с.

${ }_{23}$ Арістова I.В., Стадник Р.І. Органи виконавчої влади України як розпорядники публічної інформації: теоретико-правові та практичні питання : монографія / За заг. ред. І.В. Арістової. Київ : Видавничий центр НУБіП України, 2018. 233 с.

24 Арістова І.В. Реалізація інформаційно-правового статусу органів виконавчої влади України в інформаційних правовідносинах : монографія / За заг. ред. І.В. Арістової. Київ : Видавничий центр НУБіП України, 2015. 250 с.

25 Арістова I.В., Стадник Р.І. Органи виконавчої влади України як розпорядники публічної інформації: теоретико-правові та практичні питання : монографія / За заг. ред. І.В. Арістової. Київ : Видавничий центр НУБіП України, 2018. 233 с.

${ }^{26}$ Aristova I.V. Kaliuzhna S.V. Legal status of the public authorities of Ukraine under European integration and the information society development. Innovative scientific research: European development trends and regional aspects. Collective monograph. Riga : Izdevniecība «Baltija Publishing», 2020. P. 1. P. 68-86. 


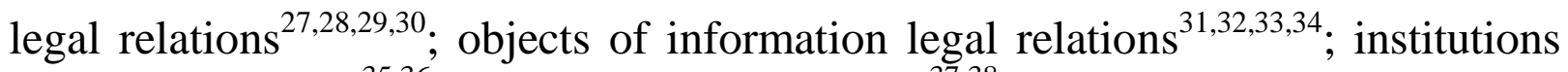
of information $\mathrm{law}^{35,36}$; forms of information law ${ }^{37,38}$; information law and order.

2. The theoretical and legal, and methodological foundations of the knowledgebased information society and the information-driven state: methodological and legal foundations for the formation of knowledge societies and their implementation in Ukraine ${ }^{39,40}$; conceptual and legal foundations of the state information policy in the context of the development of information society ${ }^{41,42}$; legal foundations for overcoming digital and cognitive inequality in the context

\footnotetext{
${ }^{27}$ Свистович Р.С. Правове регулювання інформаційних відносин у сфері масової інформації : автореф. дис. ... канд. юрид. наук : 12.00.07. Київ, 2011. 20 с.

${ }_{28}^{28}$ Арістова I.В. Реалізація інформаційно-правового статусу органів виконавчої влади України в інформаційних правовідносинах : монографія / За заг. ред. І.В. Арістової. Київ : Видавничий центр НУБіП України, 2015. 250 с.

${ }^{29}$ Арістова І.В., Стадник Р.І. Органи виконавчої влади України як розпорядники публічної інформації: теоретико-правові та практичні питання : монографія / За заг. ред. І.В. Арістової. Київ : Видавничий центр НУБіП України 2018. 233 с.

${ }^{30}$ Aristova I.V. Kaliuzhna S.V. Legal status of the public authorities of Ukraine under European integration and the information society development. Innovative scientific research: European development trends and regional aspects Collective monograph. Riga : Izdevniecība «Baltija Publishing», 2020. P. 1. P. $68-86$.

${ }^{31}$ Свистович Р.С. Правове регулювання інформаційних відносин у сфері масової інформації : автореф. дис. ... канд. юрид. наук : 12.00.07. Київ, 2011. 20 с.

32 Арістова І.В., Кузнецова М.Ю. Реалізація інформаційно-правового статусу органів виконавчої влади України в інформаційних правовідносинах : монографія / За заг. ред. І.В. Арістової. Київ : Видавничий центр НУБіП України, 2015. 250 с

33 Арістова І.В., Чернадчук В.Д. Концепція інформаційних правовідносин: сутність та особливості використання у сфері банківської діяльності. URL : https://goo.gl/6ZPуTf (дата звернення: 19.10.2020).

${ }^{34}$ Чернадчук Т.О. Актуальні питання інформаційних правовідносин у банківській сфері : монографія / За заг. ред. І.В. Арістової. Суми : Вид-во СНАУ, 2011. 162 с.

${ }^{35}$ Свистович Р.С. Правове регулювання інформаційних відносин у сфері масової інформації : автореф. дис. ... канд. юрид. наук : 12.00.07. Київ, 2011. 20 с.

${ }^{36}$ Арістова I.В., Стадник P.І. Органи виконавчої влади України як розпорядники публічної інформації: теоретико-правові та практичні питання : монографія / За заг. ред. І.В. Арістової. Київ : Видавничий центр НУБіП України 2018. 233 с.

${ }^{37}$ Арістова I.В., Ткаченко В.В. Інформаційне законодавство України: проблеми адаптації до міжнародних правових стандартів : монографія / За заг. ред. І.В. Арістової. Київ : Видавничий центр НУБіП України, 2015. 185 с.

38 Арістова I.В., Стадник Р.І. Органи виконавчої влади України як розпорядники публічної інформації: теоретико-правові та практичні питання : монографія / За заг. ред. І.В. Арістової. Київ : Видавничий центр НУБіП України 2018. 233 с

${ }^{39}$ Арістова І.В., Курило, В. І., Крегул І. Ю. Проблеми правового регулювання співробітництва України 3 міжнародною організацією ЮНЕСКО у сфері правового забезпечення розвитку інформаційного суспільства в Україні: монографія / За заг. ред. І.В. Арістової. Київ : Центр учбової літератури, 2013. 216 с.

40 Арістова І.В. Методологічні засади розбудови суспільств знань. Правова інформатика. 2008. № 3(19). C. 10-17.

${ }^{41}$ Арістова I.В. Державна інформаційна політика та їі реалізація в діяльності органів внутрішніх справ України: організаційно-правові засади : дис. ... докт. юрид. наук : 12.00.07. Харків : Національний ун-т внутр. справ, 2002. 476 с.

${ }^{42}$ Сировой О.В. Організаційно-правові засади управління інформаційними ресурсами органів внутрішніх справ України : автореф. дис... канд. юрид. наук : 12.00.07. Харків : Національний ун-т внутр. справ, 2006. $20 \mathrm{c}$.
} 
of the development of knowledge society in Ukraine ${ }^{43,44}$; comparative legal studies of the development of knowledge societies in the countries of the European Union and Ukraine ${ }^{45}$; information function of $\mathrm{law}^{46}$; information function of government bodies ${ }^{47,48}$; theory of information-driven state ${ }^{49,50}$.

3. National and international information legislation: international information legal standards ${ }^{51,52}$; comparative legal research on the processes of implementation, adaptation, harmonization and unification of Information legislation of Ukraine ${ }^{53}$; application of the concept of international "soft" law to improve the information legislation of Ukraine ${ }^{54,55}$; harmonization of the information legislation of Ukraine with international legal standards ${ }^{56}$; promising sources of information law of Ukraine $^{57,58}$; problems of bringing the information law of Ukraine in line with

43 Арістова I.В., Сулацький Д.В. Інформаційна безпека людини як споживача телекомунікаційних послуг: монографія / За заг. ред. І.В. Арістової. Харків : Право, 2013. 184 с.

${ }^{44}$ Макогонюк Ю.Ю. Організаційно-правові засади забезпечення права на доступ до публічної інформації в екологічній сфері України : дис.. канд юрид наук : 12.00.07. Київ, 2017. 241 с.

${ }_{45}$ Арістова I.В. Інформаційне суспільство та суспільства знань: порівняльно-правовий аналіз й досвід для України. Украӥнсько-грецький міжнародний науковий юридичний журнал. Порівняльно-правові дослідження. 2008. № 2. С. 27-29.

46 Арістова І.В. Державна інформаційна політика та їі реалізація в діяльності органів внутрішніх справ України: організаційно-правові засади : дис. ... докт. юрид. наук : 12.00.07. Харків : Національн. ун-т внутр. справ, 2002. $476 \mathrm{c.}$

${ }^{47}$ Арістова I.В. Реалізація інформаційно-правового статусу органів виконавчої влади України в інформаційних правовідносинах : монографія / За заг. ред. І.В. Арістової. Київ : Видавничий центр НУБіП України, 2015. 250 с.

${ }^{48}$ Арістова I.В. Державна інформаційна політика та ії реалізація в діяльності органів внутрішніх справ України: організаційно-правові засади : дис. ... докт. юрид. наук : 12.00.07. Харків : Національн. ун-т внутр. справ, 2002. 476 c.

49 Там само.

50 Арістова І.В., Бєлявська С.Ю. Удосконалення судового управління в Україні: організаційно-правові засади впровадження інновацій : монографія. Київ : НУБіП України, 2016. 194 с.

${ }^{51}$ Арістова I.В., Ткаченко В.В. Інформаційне законодавство України: проблеми адаптації до міжнародних правових стандартів : монографія / За заг. ред. І.В. Арістової. Київ : Видавничий центр НУБіП України, 2015. 185 с.

52 Арістова І.В., Курило В.І., Крегул І.Ю. Проблеми правового регулювання співробітництва України з міжнародною організацією ЮНЕСКО у сфері правового забезпечення розвитку інформаційного суспільства в Україні : монографія / За заг. ред. І.В. Арістової. Київ : Центр учбової літератури, 2013. 216 с.

${ }^{53}$ Арістова I.В., Ткаченко В.В. Інформаційне законодавство України: проблеми адаптації до міжнародних правових стандартів : монографія / За заг. ред. І.В. Арістової. Київ : Видавничий центр НУБіП України, 2015. 185 с.

54 Там само.

55 Арістова І.В., Курило, В.І., Крегул І.Ю. Проблеми правового регулювання співробітництва України з міжнародною організацією ЮНЕСКО у сфері правового забезпечення розвитку інформаційного суспільства в Україні: монографія / За заг. ред. І. В. Арістової. Київ : Центр учбової літератури, 2013. 216 с.

${ }^{56}$ Арістова I.В., Ткаченко В.В. Інформаційне законодавство України: проблеми адаптації до міжнародних правових стандартів : монографія / За заг. ред. І.В. Арістової. Київ : Видавничий центр НУБіП України, 2015. 185 с.

57 Там само.

58 Арістова І.В., Курило, В.І., Крегул І.Ю. Проблеми правового регулювання співробітництва України 3 міжнародною організацією ЮНЕСКО у сфері правового забезпечення розвитку інформаційного суспільства в Україні: монографія / За заг. ред. І В. Арістової. Київ : Центр учбової літератури, 2013. 216 с. 
international law ${ }^{59}$; international cooperation of Ukraine with international organizations in the field of legal support for the development of information society (knowledge society) in Ukraine ${ }^{60}$.

4. The development of the information-driven state in Ukraine: organizational and legal basis for the introduction of information and communication technologies (hereinafter referred to as the ICT) and other innovations of the information society, based on knowledge, in the activities of government bodies and local self-government authorities, as well as various spheres of public life; organizational and legal basis for the introduction of ICT in the agrarian sector of the economy of Ukraine ${ }^{61}$; organizational and legal basis for the introduction of innovations in judicial administration in the conditions of the information society in Ukraine ${ }^{62}$; information legal and administrative legal support for the provision of administrative and information services in the context of the information society and the development of the information-driven state ${ }^{63} 64$.

It should be noted that certain elements of the research program have been already largely developed, as evidenced by the references made to the relevant studies.

We consider it appropriate to emphasize that the new conditions of the present time, amendments to the legislation of Ukraine, as well as the new legal knowledge gained by representatives of other scientific schools, primarily in the field of information law, are embodied in the adjustment of certain provisions of the program, for example, to establish interaction with scientists in the field of environmental, agrarian and land law during the study of the problem on ensuring proper legal regulation of complicated public relations (ecological information, information agrarian, land information) ${ }^{65}$, emerging from the development of knowledge-based information society.

\footnotetext{
${ }^{59}$ Арістова I.В., Ткаченко В.В. Інформаційне законодавство України: проблеми адаптації до міжнародних правових стандартів : монографія / За заг. ред. І.В. Арістової. Київ : Видавничий центр НУБіП України, 2015. 185 с.

${ }^{60}$ Арістова І.В., Курило, В.І., Крегул І.Ю. Проблеми правового регулювання співробітництва України 3 міжнародною організацією ЮНЕСКО у сфері правового забезпечення розвитку інформаційного суспільства в Україні: монографія / За заг. ред. І.В. Арістової. Київ : Центр учбової літератури, 2013. 216 с.

${ }^{61}$ Арістова I.В., Курило В.І., Калугін О.Ю. Впровадження інформаційно-комунікаційних технологій в аграрний сектор економіки України: організаційно-правовий аспект: монографія / За заг. ред. I.В. Арістової. Київ : Редакційно-видавничий центр НУБіП України, 2014. 193 с.

62 Арістова І.В., Бєлявська С.Ю. Удосконалення судового управління в Україні: організаційно-правові засади впровадження інновацій : монографія / За заг. ред. І.В. Арістової. Київ : НУБіП України, 2016. 194 с.

${ }^{63}$ Арістова I.В., Сулацький Д.В. Інформаційна безпека людини як споживача телекомунікаційних послуг : монографія / За заг. ред. І.В. Арістової. Харків : Право, 2013. 184 с.

${ }^{64}$ Арістова I.В., Курило В.І., Скоромний Я.І. Організаційно-правові засади надання адміністративних послуг у сільському господарстві України: монографія / За заг. ред. І. В. Арістової. Київ : Видавництво центр НУБіП України, 2015. 156 с.

${ }_{65}$ Арістова I.В., Шульга М.В. Правове регулювання суспільних відносин у межах наукових спеціальностей 12.00.06 та 12.00.07: методологічний аспект. Актуальні проблеми екологічних, земельних та аграрних правовідносин: методологічні й прикладні аспекти: матеріали круглого столу (м. Харків, 5 грудня 2014 року). Харків : Національний юридичний університет ім. Ярослава Мудрого. 2014. С. $22-25$.
} 
It should be noted that the article focuses on the expediency of considering the obtained scientific results (within the framework of the above scientific school) for the purpose of "taking deliberate, concrete and targeted steps to achieve the goal to be sought". This is not the "past", but the "foundation for the future" proper law and order in the knowledge society in Ukraine. It is from this position that it is proposed to determine the scientific legal knowledge that appears as certain building blocks for the formation of models, theories, and concepts of the science of information law.

Not only in our opinion, but also in the opinion of scientists in the field of information law, the formation of the scientific school headed by the author of the article (I.V. Aristova), in a historical perspective, began eighteen years ago with the defense of thesis for a doctor's degree on the topic "State Information Policy and its Implementation in the Activities of the Internal Affairs Bodies of Ukraine: Organizational and Legal Foundations" acquired scientific knowledge relevant for solving the urgent needs of our time? In our opinion, the answer is "Yes". Let us assure ourselves of this.

First, the results obtained in the paper ${ }^{67}$ are theoretical, legal and methodological foundations for the development of a knowledge-based information society (this is the second direction of the research program of the scientific school). In the scientific community, scholars use the conceptual framework defined in the paper $^{68}$. First of all, we are talking about the following concepts: 1) "information society" is a civil society with developed information production and a high level of information and legal culture, in which the effectiveness of people's activities is provided by a variety of services based on intelligent information technologies and communication technologies; 2) "information-driven state" is a democratic, social, legal state, the effectiveness of which is provided by a variety of services based on intelligent information technologies and communication technologies. One of the provisions of the work ${ }^{69}$ is constructively used in modern scientific developments: the theoretical and methodological foundations of the formation of government information policy are one of the prerequisites for the development of information society and information-driven state. The proper implementation of the government information policy is essential in order to achieve success in the formation of information society. For the first time, the implementation of the government information policy has been understood as the public management of the national information sphere (hereinafter referred to as the NIS).

\footnotetext{
${ }^{66}$ Арістова I.В. Державна інформаційна політика та їі реалізація в діяльності органів внутрішніх справ України: організаційно-правові засади : дис. ... докт. юрид. наук : 12.00.07. Харків : Національн. ун-т внутр. справ, 2002. 476 с.

67 Там само.

68 Там само.

69 Там само.
} 
Secondly, the following scientific provisions are innovative for modern jurisprudence as well ${ }^{70}$ :

- for the first time the problem of correlation of purely management and information functions of the public management of NIS has been analyzed in a historical perspective and may be schematically presented as follows: information function - direction of management function; information function is independent, management function contributes to its organization; management function turn into information in a broad sense. By the way, this position is presented based on the scope of the information function at certain stages of the development of information society;

- for the first time in the theory of public management and administrative and information law it has been proposed to consider the integrative development of information functions of the state and law as one of the important factors in the transformation of the state into information-driven;

- for the first time, the essence of information relations (production dissemination - consumption) and its significance for scientific support of the systematization of information legislation have been substantiated, and will enable to predict the emergence of potential problems of the information space (proposals are included in the draft Law of Ukraine "Concept of Reforming the Legislation of Ukraine in the Field of Public Information Relations").

Thus, it is established that the paper ${ }^{71}$ focuses on the need to consider information relations between the object and subject of the public management of NIS, based on the idea of gradual transformation of management relations into information in their broad interpretation. The formation of information legislation is considered as an overriding priority of the public management of NIS, taking into account the need for evenhanded legal regulation of information relations in the information society. The authors have proposed the conceptual foundations of information legislation reforming, which involve the following: continental doctrine of law is the basis for rulemaking in the field of public information relations; information legislation is an integrated branch of legislation; the systematization of information legislation is codification. In the course of their implementation, two approaches may be used: to start from the totality of the most acute information problems of today's world; to proceed from the essence of information relations, preventing the emergence of new problems. The second approach is considered a priority in the work. It is noted that scientific support for the systematization of information legislation requires, first of all, the early

\footnotetext{
${ }^{70}$ Арістова І.В. Державна інформаційна політика та їі реалізація в діяльності органів внутрішніх справ України: організаційно-правові засади : дис. ... докт. юрид. наук : 12.00.07. Харків : Національн. ун-т внутр. справ, 2002. $476 \mathrm{c}$.

71 Там само.
} 
adoption of the Law of Ukraine "On Laws and Legislative Activity" by the Verkhovna Rada of Ukraine. It should be mentioned that Ukrainian scientists note that in this work ${ }^{72}$ the first steps are taken towards positioning information law as an independent branch of law.

Undoubtedly, over the years, some provisions of this work ${ }^{73}$ have found their further development, for example: 1) understanding the transformation of information society into knowledge society ${ }^{74,75,76,77 ;}$ ) awareness of the need to develop a scientific doctrine of information law in the information society built on knowledge ${ }^{78}$; 3) establishing the expediency of developing the concept of information legal relations ${ }^{79}$, justifying the emergence of integrated legal relations (information and administrative, information and financial, information and environmental, etc.), introducing the concept "integrative information sphere" into scientific circulation ${ }^{80,81}$; 4) working out ways to search for promising sources of information law of Ukraine ${ }^{82,83}$; 5) substantiating the methodology of the science of information law, a cognitive model of the science of information law, determining standards in the activities of any subject conducting scientific research in the field of information law, etc. ${ }^{84,85}$

\footnotetext{
72 Арістова І.В. Державна інформаційна політика та іiі реалізація в діяльності органів внутрішніх справ України: організаційно-правові засади : дис. ... докт. юрид. наук : 12.00.07. Харків : Національн. ун-т внутр. справ, 2002. 476 c.

73 Там само.
}

74 Арістова І.В. Методологічні засади розбудови суспільств знань. Правова інформатика. 2008. № 3(19). C. 10-17.

75 Арістова І.В. Інформаційне суспільство та суспільства знань: порівняльно-правовий аналіз й досвід для України. Украӥнсько - грецький міжнародний науковий юридичний журнал. Порівняльно-правові дослідження. 2008. № 2. С. 27-29.

${ }^{76}$ Арістова I.В. Організаційно-правові механізми ЮНЕСКО щодо розвитку інформаційного суспільства: орієнтир для України. Правова інформатика. 2009. № 1. С. 17-21.

77 Арістова I.В. Розбудова правової держави в Україні: правовий механізм забезпечення права на доступ до інформації в суспільстві знань. Правова інформатика. 2010. № 1. С. 3-13.

78 Арістова I.В. Наука «інформаційне право» на новому етапі розвитку інформаційного суспільства. Правова інформатика. 2011. № 1. С. 3-11.

79 Арістова I.В., Чернадчук В.Д. Концепція інформаційних правовідносин: сутність та особливості використання у сфері банківської діяльності. URL : https://goo.gl/6ZРуTf (дата звернення: 19.10.2020).

${ }^{80}$ Арістова І.В., Кузнецова М.Ю. Реалізація інформаційно-правового статусу органів виконавчої влади України в інформаційних правовідносинах : монографія / За заг. ред. І.В. Арістової. Київ : Видавничий центр НУБіП України, 2015. 250 с.

81 Арістова I.В., Чернадчук В.Д. Концепція інформаційних правовідносин: сутність та особливості використання у сфері банківської діяльності. URL : https://goo.gl/6ZРуTf (дата звернення: 19.10.2020).

${ }^{82}$ Арістова I.В., Ткаченко В.В. Інформаційне законодавство України: проблеми адаптації до міжнародних правових стандартів : монографія / За заг. ред. І.В. Арістової. Київ : Видавничий центр НУБіП України, 2015. 185 с.

${ }^{83}$ Арістова І.В., Курило, В І., Крегул І.Ю. Проблеми правового регулювання співробітництва України 3 міжнародною організацією ЮНЕСКО у сфері правового забезпечення розвитку інформаційного суспільства в Україні : монографія / За заг. ред. І.В. Арістової. Київ : Центр учбової літератури, 2013. 216 с.

${ }^{84}$ Арістова І.В. Становлення науки «інформаційне право»: питання методології. Ч. І. Публічне право. 2016 p. № 2. C. 245-250.

85 Арістова І.В. Становлення науки «інформаційне право»: питання методології. Ч. 2. Публічне право. 2016 p. № 3. C. 232-243. 
It is worth emphasizing that the significant scientific results have been obtained due to the operation of this scientific school. By the way, this fact has been noted by well-known scientists and confirmed by the Yaroslav the Wise Award in 2013 for outstanding achievements in research activities on the problems of law. In our opinion, the presentation of those scientific provisions that fall primarily under the heading "for the first time" may contribute to the awareness of the level of scientific results obtained by representatives of the scientific school. The coverage of the main results of the scientific school will be carried out in the second part of the article.

\section{Genesis of the results of the scientific school in the field of information law: problems, solutions, prospects}

Based on the results obtained in the first part of the article, we will focus our research on achieving the fourth component of the goal, that is: 1) in the historical perspective, we will find out the main results of the scientific school headed by one of the authors of the article (I. V. Aristova); 2) establish both their inheritance and deeper insight; 3) identify problem points; 4) outline possible ways to overcome problems and promising directions of the research program of the scientific school "Legal Foundations of the Information Society Based on Knowledge and the Information-Driven State". It should be emphasized that the research program has been developed, based on the need to conduct scientific research not only in the field of information law, but also taking into account the interaction of information law with other branches of law (administrative, financial, environmental, agricultural, etc.) under the development of the information society based on knowledge and the information-driven state in Ukraine.

It is worth noting that one of the first works studying the development of the information function of government bodies of Ukraine, its interaction with the management function of these bodies, as well as legal support (information legal, administrative legal) for the implementation of these functions, is the thesis of O. V. Syrovoi on the topic "Organizational and Legal Bases for Managing Information Resources of Internal Affairs Agencies of Ukraine" ${ }^{" 86}$. We believe that at the time of the defense of this work (2006), the scientific novelty was determined primarily by the fact that by both the problem statement and the approach to its solution, the thesis was one of the first comprehensive studies of this problem in Ukrainian legal science (information and administrative law).

\footnotetext{
${ }^{86}$ Сировой О.В. Організаційно-правові засади управління інформаційними ресурсами органів внутрішніх справ України : автореф. дис... канд. юрид. наук : 12.00.07. Харків : Національний ун-т внутр. справ, 2006. 20 c.
} 
At the same time, there is also inheritance in the use of the model of the public management of the national information sphere (hereinafter - NIS) proposed by I.V. Aristova (one of the authors of the article) and the scientific supervisor of the candidate for a degree in the work ${ }^{87}$. On the other hand, O. V. Syrovoi reasonably suggests studying the management of information resources of the Internal Affairs Agencies of Ukraine as a component of the NIS management system. In our opinion, the work ${ }^{88}$ clearly demonstrates the systematic worldview of the thesis's author, which is manifested primarily: 1) in the author's vision of the mechanism for managing information resources of the Internal Affairs Agencies of Ukraine; 2 ) in the interpretation of the concept of information resources; 3) in proposals for the formation and use of systematized accounting of regulatory legal acts (administrative legal and information legal nature) of the Internal Affairs Agencies of Ukraine using the latest information technologies; 4) in understanding the need to carefully implement international information and legal standards of information activity in the information legislation of Ukraine, etc. Undoubtedly, innovative both at that time and today are the proposals ${ }^{89}$ for: 1) providing individuals and legal entities with public information owned by the Internal Affairs Agencies of Ukraine; 2) legislative enshrinement of the institution of legal regime of information resources, which will contribute to the streamlining of relevant information relations. I believe that the main conclusions of the work ${ }^{90}$ may be useful, in particular, during: 1) implementation of provisions of the Law of Ukraine "On Access to Public Information" by the Internal Affairs Agencies of Ukraine as the owners of public information; 2) departmental information lawmaking; 3) scientific study of the problem of information and legal status of the Internal Affairs Agencies of Ukraine.

It is worth emphasizing that inheritance and common scientific views are also found in other studies that have been and are being conducted within the framework of the scientific school. For example, in the thesis research "Legal Regulation of Information Relations in the Field of Mass Information" "91, the concept of information legal relations highlighted, in particular, in the work ${ }^{92}$, has been constructively introduced in the field of mass information. At the same time,

\footnotetext{
${ }^{87}$ Арістова І.В. Державна інформаційна політика та їі реалізація в діяльності органів внутрішніх справ України: організаційно-правові засади : дис. ... докт. юрид. наук : 12.00.07. Харків : Національний ун-т внутр. справ, 2002. 476 с.

${ }^{88}$ Сировой О.В. Організаційно-правові засади управління інформаційними ресурсами органів внутрішніх справ України : автореф. дис... канд. юрид. наук : 12.00.07. Харків : Національний ун-т внутр. справ, 2006. 20 с.

${ }^{89}$ Там само.

90 Там само.

91 Свистович Р.С. Правове регулювання інформаційних відносин у сфері масової інформації : автореф. дис. ... канд. юрид. наук : 12.00.07 / К., 2011. 20 с.

92 Арістова I.В., Чернадчук В.Д. Концепція інформаційних правовідносин: сутність та особливості використання у сфері банківської діяльності. URL : https://goo.gl/6ZРуTf (дата звернення: 19.10.2020).
} 
for the first time ${ }^{93}$ the authors of the paper have proposed and justified: 1) their own concept of the formation of theoretical and methodological foundations of legal regulation of information relations in the field of mass information, which relate to the state policy on the development of information society in Ukraine; the formation of the science of information law and the relevant integrated branch of law; the conceptual and categorical framework of the science of information law; the genesis of the essence and concept of information legal relations in the scientific doctrine, their classification and features; the general legal characteristics of the sphere of mass information; 2) the expediency of developing and implementing a qualitatively new model of legal regulation of information relations in the field of mass information, which proceeds from the concept of theoretical and methodological foundations of this legal regulation; the need to take into account the statics and dynamics of legal regulation; the importance of observing the principle of freedom of mass information; 3) features of the legal regulation of information relations in the field of mass information, which are underpinned, on the one hand, by the specifics of components of the field of mass information (according to a certain classification - the sector of traditional mass media and the sector of electronic mass media (hereinafter referred to as the media) and, on the other, the conscious selection of a simple process of legal regulation and lawful behavior of subjects of information legal relations.

In our opinion, this work ${ }^{94}$ is characterized by the fact that its main provisions and conclusions may be the basis for further improvement of the integrated institution of law - mass media law - in the context of the development of knowledge society in Ukraine. For example, realizing the importance of proper legal regulation of information relations in the sub-sphere of electronic media the Internet, we consider it expedient to emphasize that it is essential to conduct in this sphere specific scientific research, the basis of which may be a model of legal regulation of information relations in the field of mass information proposed in the paper. At the same time, the paper ${ }^{95}$ focuses on the expediency of considering: special principles, when ensuring legal support for information relations on the Internet; supranational nature of the regulation of information relations; international experience in legal regulation of information relations in the electronic media sector.

Scientific problems in the field of information law related to the insufficient study of the concept of information legal relations in various spheres of public life, as well as the need for practice to ensure an appropriate level of legal regulation of complex public relations (the structure includes two or more public

\footnotetext{
93 Свистович Р. С. Правове регулювання інформаційних відносин у сфері масової інформаці ї: автореф. дис. ... канд. юрид. наук : 12.00.07 / Київ, 2011. 20 с.

94 Там само.

95 Там само.
} 
relations) have given rise to the scientific study "Topical Issues of Information Legal Relations in the Banking Sector" ${ }^{\prime 96}$. It is worth emphasizing that one of the innovations of this work is the justification of the need for interaction between information and banking law during the operation of the mechanism of legal regulation of the relevant range of public relations (information, banking). It is beyond argument that the following provisions of the work ${ }^{97}$ are innovative: 1) the features of information legal relations in the field of banking under the development of information society, determined by the scope of their origin and development, functional purpose, object and subject composition, have been revealed; 2) it is reasonably proposed to introduce into terminology the concept "information banking legal relations", which are understood as public relations regulated by the rules of information and banking law that arise between authorized and obligated entities as a result of the exercise of their information powers in the field of banking; 3) a model of legal regulation of information relations in the field of banking, which is based on the concept of theoretical and methodological support for such regulation; pluralistic concept of defining the objects of information banking legal relations, the need to comply with the principles of banking and information activities; the need to take into account the static and dynamic component of legal regulation, has been proposed and justified.

The conducted research of theoretical aspects of information banking legal relations and their current state has revealed a number of problems of a scientific and practical nature that require both scientific and legislative solutions. The monograph ${ }^{98}$ has made an attempt to highlight the authors' own vision of solving some of them, identified the shortcomings of the current information and banking legislation, provided suggestions for improving the legal regulation of information relations in the banking sector, and identified areas for improving legislation. Undoubtedly, the theoretical views and practical proposals presented in the monograph ${ }^{99}$ may not be considered to be a permanent solution to all the problems of information banking legal relations, some of them are debatable in nature, others require further research, therefore, the scientific search may and should be continued. However, certain conceptual provisions of the monographic study should be used as starting points for further research.

It should be emphasized that the further development of the concept of information legal relations is covered in another study carried out within the

\footnotetext{
96 Чернадчук Т.О. Актуальні питання інформаційних правовідносин у банківській сфер і: монографія / За заг. ред. І В. Арістової. Суми : Вид-во СНАУ, 2011. 162 с.

97 Там само.

98 Чернадчук Т.О. Актуальні питання інформаційних правовідносин у банківській сфері : монографія / За заг. ред. І.В. Арістової. Суми : Вид-во СНАУ, 2011. 162 с.

${ }^{99}$ Там само.
} 
framework of the scientific school ${ }^{100}$. Having regard to the fact that the category of information legal relations is important not only for the theory, but also for the practical activities of executive authorities of Ukraine as participants in these legal relations, there has been an urgent need to conduct relevant research. At the same time, this work constructively uses the conclusions obtained in the study ${ }^{101}$, regarding the allocation of the information function of government authorities and strengthening its importance in a developed information society.

We believe that the following scientific results ${ }^{102}$ have primarily contributed to the development of the scientific school: 1) it is justified that the development of the information function of executive authorities (hereinafter referred to as the EAs) of Ukraine, as an independent function, determines the establishment of information and legal status of these authorities as a collective subject of information law, which is enshrined in the legal sources of law; it is argued that the information function of executive authorities is reflected in the relevant regulatory legal acts through the consolidation of goals, objectives, and information and legal powers;

2) the concept of implementation of information and legal status of executive authorities of Ukraine in information legal relations arising in the field of personal data and public information has been proposed and justified. The main provisions of the concept are: a) broad interpretation of the concept of information legal relations; b) objectivity in the formation of complex legal relations (in particular, complex ones that have arisen during legal regulation by both the rules of information law and the rules of other branches of law); c) reference point for determining the structure of information and legal status of these authorities is the structure of their administrative and legal status; d) narrow interpretation of the concept of information and legal status of executive authorities of Ukraine: its content is information competence in a narrow sense, namely information and legal powers; e) information and legal powers are determined depending on the functions of the executive authorities of Ukraine, which are legally assigned to these bodies in the field of personal data and public information (for example, owner, third party);

3) a comprehensive approach to determining the list and types of information legal relations that arise both in the field of personal data and public information

\footnotetext{
${ }^{100}$ Арістова І.В., Кузнецова М.Ю. Реалізація інформаційно-правового статусу органів виконавчої влади України в інформаційних правовідносинах : монографія / За заг. ред. І.В. Арістової. Київ : Видавничий центр НУБіП України, 2015. 250 с.

${ }^{101}$ Арістова І.В. Державна інформаційна політика та їі реалізація в діяльності органів внутрішніх справ України: організаційно-правові засади : дис. ... докт. юрид. наук : 12.00.07. Харків : Національний ун-т внутр. справ, 2002. 476 с.

${ }^{102}$ Арістова І.В., Кузнецова М.Ю. Реалізація інформаційно-правового статусу органів виконавчої влади України в інформаційних правовідносинах : монографія / За заг. ред. І.В. Арістової. Київ : Видавничий центр НУБіП України, 2015. 250 с.
} 
with the participation of executive authorities of Ukraine is proposed and justified; the approach is based on determining the following criteria for classifying information legal relations in the above fields: "by subjects of legal relations", "by object of legal relations", "by mode of access to public information", "by legal nature of legal relations", "by legislative structure of the sphere of personal data", "by series of actions", "by forms and categories of personal data processing", etc. The creation of a system model of information legal relations in these fields enables to clarify the specifics of implementing the information and legal status of the specified authorities and develop appropriate proposals for its correction.

We believe that there are reasons to emphasize the practical significance of the conclusions obtained in this paper ${ }^{103}$ for improving the activities of the Internal Affairs Agencies of Ukraine to ensure the information rights of Ukrainian citizens, creating legal bases for the development of information society. It is important that the authors have made the proposals, for example, regarding: 1) the draft Code of Ukraine on Information, which relate to the definition of the concepts "information and legal relations", "information and legal status", "information and legal powers"; 2) the Laws of Ukraine "On the Cabinet of Ministers of Ukraine", "On Central Executive Authorities of Ukraine", which relate to the legislative consolidation of the information function of the executive authorities under the development of information society in Ukraine and the corresponding information and legal status of these authorities for proper implementation of the information function.

Realizing the relevance of developing a qualitatively new approach to the formation of information legislation of Ukraine, which is the legal source of information Law of Ukraine, as well as taking into account the strengthening of the international aspect of national information law and legislation, the research supervisor of the school has initiated relevant studies ${ }^{104,105}$. First of all, it is worth emphasizing that quite logical continuation of the research ${ }^{106}$ is at the same time the study of the problem of establishing new institutions of information law, including the institute of international cooperation in the development of information society. The analysis of the role of UNESCO in forming

\footnotetext{
103 Арістова І.В., Кузнецова М.Ю. Реалізація інформаційно-правового статусу органів виконавчої влади України в інформаційних правовідносинах : монографія / За заг. ред. І.В. Арістової. Київ : Видавничий центр НУБіП України, 2015. 250 с.

${ }^{104}$ Арістова I.В., Ткаченко В.В. Інформаційне законодавство України: проблеми адаптації до міжнародних правових стандартів : монографія / За заг. ред. І.В. Арістової. Київ : Видавничий центр НУБіП України, 2015. 185 с.

105 Арістова І.В., Курило, В.І., Крегул І.Ю. Проблеми правового регулювання співробітництва України з міжнародною організацією ЮНЕСКО у сфері правового забезпечення розвитку інформаційного суспільства в Україні : монографія / За заг. ред. І.В. Арістової. Київ : Центр учбової літератури, 2013. 216 с.

${ }^{106}$ Арістова I.В. Організаційно-правові механізми ЮНЕСКО щодо розвитку інформаційного суспільства: орієнтир для України. Правова інформатика. 2009. № 1. С. 17-21.
} 
recommendations for the development of a knowledge-based information society ${ }^{107}$ enables to conclude that it is expedient to conduct research on the subinstitute of international cooperation between Ukraine and UNESCO in the field of legal support for the development of the information society in Ukraine. In our opinion, the scientific school of information law has taken its next step thanks to the following results ${ }^{108}$ :

1) a model of the organizational and legal mechanism of cooperation between Ukraine and UNESCO, based on the specifics of institutional and legal support for cooperation both on the part of Ukraine and UNESCO, as well as on a systematic view of the mechanism, has been proposed and justified;

2) an approach to the formation and improvement of the sphere of legal support for the development of information society in Ukraine, which from a holistic perspective takes into account the national and international components, conditioned upon UNESCO's decisive contribution to the development of the legal basis of knowledge-based societies;

3) a model of the international component of the sphere of legal support for the development of information society in Ukraine has been proposed and justified, and takes into account: cooperation of Ukraine with UNESCO; classification of the sphere by the criterion of the variety of UNESCO's international acts; the possibility of considering the international component of the sphere as a "source" for improving the national component of this sphere; the unifying and coordinating nature of international and national information law;

4) the concept of legal sources of information law, among which the leading place is occupied by information legislation, the systematization (codification) of which should be preceded by the stage of introducing the concept of international "soft law" (primarily information) into law-making, which includes, among other things, UNESCO's recommendation legal rules for the development of knowledge-based societies ${ }^{109}$, has been further developed.

In our opinion, the conducted research ${ }^{110}$ has proved that the rules of international "soft law" (both legal and non-legal) are an essential element of the international legal system, and it is expedient to learn how to use these regulatory tools when creating the legal basis of the knowledge society in Ukraine. The results obtained in this paper ${ }^{111}$ have contributed to further promotion of research on improving the information legislation of Ukraine by adjusting it to

\footnotetext{
107 Арістова І.В. Організаційно-правові механізми ЮНЕСКО щодо розвитку інформаційного суспільства: орієнтир для України. Правова інформатика. 2009. № 1. С. 17-21.

108 Арістова I.В., Курило, В.І., Крегул І.Ю. Проблеми правового регулювання співробітництва України з міжнародною організацією ЮНЕСКО у сфері правового забезпечення розвитку інформаційного суспільства в Україні: монографія / За заг. ред. І.В. Арістової. КИїВ : Центр учбової літератури, 2013. 216 с.

${ }^{109}$ Там само.

110 Там само.

111 Там само.
} 
international legal standards under the development of information society in Ukraine ${ }^{112}$. We consider it appropriate to focus on the main provisions of the work $^{113}$, which significantly enrich the scientific school on information law:

- for the first time, the expediency of considering the adjustment of the information legislation of Ukraine to international legal standards under the development of information society as a process related to the peculiarities of interaction of the rules of national information law with the rules of international information law, as well as to the mechanism for applying the latter in the field of intrastate information relations, which is based on the provisions of the theory of implementation, has been proposed and justified;

- for the first time, a system model of the conceptual foundations for adjusting the information legislation of Ukraine to international legal standards under the development of information society has been proposed; five main conceptual foundations, such as the content and features of adjustment, information legislation of Ukraine, international information and legal standards, conditions for the development of information society, features of international information law, have been studied as interacting elements

- for the first time, a comprehensive approach to the study of the process of bringing the information legislation of Ukraine in line with international legal standards under the development of information society, which takes into account the system of security organizational and legal measures (a prerequisite) and the system of conceptual foundations (a sufficient condition), has been proposed and justified;

- the conceptual framework of the science of information law has been developed, namely: the definition of the concept "bringing the information legislation of Ukraine in line with international legal standards under the development of information society", "international legal standards", "information legislation of Ukraine", "promising legal sources of information law of Ukraine";

- the characteristics of the functions of information law has been further developed, namely: a integration (integrative) function, which is for this branch of law, has been highlighted in order to further use it as one of the main characteristics of the information legislation of Ukraine under the globalization of information society;

- the approach to the formation of new legal sources of information law of Ukraine, which provides for a reasonable selection of promising sources of this law from acts of international information legislation, has been improved ${ }^{114}$.

\footnotetext{
${ }^{112}$ Арістова I.В., Ткаченко В.В. Інформаційне законодавство України: проблеми адаптації до міжнародних правових стандартів : монографія / За заг. ред. І.В. Арістової. Київ : Видавничий центр НУБіП України, 2015. 185 с.

113 Там само.
} 
It should be noted that the studies ${ }^{115}$, based on the need to activate scientific research on the development of various legal models, constructions and theories, which together will form the doctrine of information law, determines some scientific areas, the promotion of which will contribute not only to the development of the science of information law, but also to improvement in the adjustment of information legislation. In particular, further scientific research should be related to 1) taking into account in the research the adjustment of the information legislation of Ukraine, in addition to regulatory, institutional and functional parts of the legal system; 2) constructive use of special methods of legal convergence during adjustment. In our opinion, this will contribute to the formation and development of the institute of information law - bringing the rules of national information law in line with the rules of international information law. At the same time, this will clarify the tasks of harmonizing information legislation with international legal standards, which are enshrined in the plan of organizational and legal measures to fulfill the tasks provided for by the Law of Ukraine "On Basic Principles of Information Society Development for 2007-2015".

Given the restrictions on the volume of publication, this article does not consider all areas of activity of the scientific school. At the same time, even the scientific results presented in the paper enable to make sure that the goal of the article has been achieved to a large extent.

\section{CONCLUSIONS}

The conducted research enables to state the following:

1. It is established that scientific schools in the field of information law: a) contribute to the introduction of a new ethics of legal knowledge in the context of the development of knowledge society in Ukraine; b) become an element of the system of ensuring proper law and order in the knowledge society; c) influence the development of the science of information law.

2. The common idea of forming a scientific school involving the development and implementation of legal bases for the development of a knowledge-based information society and information-driven state has been determined.

3. The fundamental principles of creating a scientific school in the field of information law are outlined, which, at the same time, are distinctive features of the common scientific views of the school's researchers.

4. The school's research program has been developed on the system-related bases. The structure and content of each subsystem (component) of the research

\footnotetext{
114 Арістова I.В., Ткаченко В.В. Інформаційне законодавство України: проблеми адаптації до міжнародних правових стандартів : монографія / За заг. ред. І.В. Арістової. Київ : Видавничий центр НУБіП України, 2015. 185 с.

115 Там само.
} 
program are determined (taking into account the specified classification criteria). Links to scientific works carried out under the research program are provided.

5. In a historical perspective (from 2006 to 2020), certain directions of the development of the scientific school of information law have been identified, and the main scientific results that contribute to the formation of the doctrine of Information law have been clarified.

6 . The trend in developing the concept of information legal relations, the concept of search for promising sources of information law of Ukraine, as well as the trend in developing the functions of information law and the information function of the state under the formation of an information society based on knowledge, have been identified.

7. Problematic issues, which, in particular, are related to the legal regulation of information relations in the field of non-traditional (electronic) mass media, in the banking sector, as well as with the formation of information legislation of Ukraine, have been identified.

8. The approaches to the formation of legal support for the development of the information society based on knowledge in Ukraine, activation of interaction of branches of national law, formation of a new integrative concept of interaction of international and national law rules, development of the integration function of information law of Ukraine have been proposed.

We consider it appropriate in subsequent publications to focus on the results in other areas of research of the scientific school of information law.

\section{SUMMARY}

The article is devoted to determining the place and role of scientific schools in the field of information law in ensuring law and order in the knowledge society in Ukraine and the development of the science of information law. The author's vision of the concept of fundamental principles of creating a scientific school in the field of information law is proposed and justified. The main areas of the research program of the scientific school on information law are determined.

The main results of the scientific school's activity on information law for a certain historical period are determined. The article substantiates the inheritance and deepening of research in certain areas of operation of the scientific school, which contribute to the formation of the doctrine of information law. The trends in developing the concept of information legal relations, the concept of search for promising sources of information law of Ukraine, as well as the trends in developing the functions of information law and the information function of the state under the formation of an information society based on knowledge, are identified. Problematic issues, which, in particular, are related to the legal regulation of information relations in the field of non-traditional (electronic) mass media, in the banking 
sector, as well as with the formation of information legislation of Ukraine, are identified. The approaches to the formation of legal support for the development of the information society based on knowledge in Ukraine, activation of interaction of branches of national law, formation of a new integrative concept of interaction of international and national law rules, development of the integration function of information law of Ukraine are proposed.

\section{REFERENCES}

1. Про Основні засади розвитку інформаційного суспільства в Україні на 2007-2015 роки : Закон України від 09.01.2007. URL : https://goo.gl/oPp05P (дата звернення: 18.10.2020).

2. К обществам знаний: Всемирный доклад ЮНЕСКО. Париж : Изд-во ЮНЕСКО, 2005. $211 \mathrm{c}$.

3. Вдосконалення вищої правничої (юридичної) освіти для фахової підготовки правника відповідно до європейських стандартів вищої освіти та правничої професії. Проект Концепції від 14.09.2016. URL : https://goo.gl/ BBB1OL (дата звернення: 18.10.2020).

4. Пилипчук В.Г., Фурашев В.М. Трансформація Центру правової інформатики в Науково-дослідний інститут інформатики і права: становлення, здобутки, пріоритети (2011-205 p.p.): науково-інформаційний огляд. За інформаційно-технічної підтримки В.М. Брижка, В.М. Поперечнюк, О.Г. Родзієвської. Київ : ТОВ «ПанТот», 2016. 106 с.

5. Положення про наукові школи Науково-дослідного інституту інформатики і права НАПрН України: протокол засідання Вченої ради від 9 грудня 2015 року № 8. URL : https://goo.gl/B1CmYU (дата звернення: 18.10.2020).

6. Про затвердження примірного переліку та опису предметних напрямів досліджень в межах спеціальності 081 «Право» : Наказ МОН України від 28.12.2018 № 1477. URL : https://zakon.rada.gov.ua/go/v1477729-18 (дата звернення: 19.10 .2020$)$.

7. Арістова I.В. Наука «інформаційне право» на новому етапі розвитку інформаційного суспільства. Правова інформатика. 2011. № 1. С. 3-11.

8. Арістова І.В. Становлення науки «інформаційне право»: питання методології. Ч. І. Публічне право. 2016 р. № 2. С. 245-250.

9. Арістова І.В. Становлення науки «інформаційне право»: питання методології. Ч. 2. Публічне право. 2016 р. № 3. С. 232-243.

10. Свистович Р.С. Правове регулювання інформаційних відносин у сфері масової інформації : автореф. дис... канд. юрид. наук : 12.00.07. Київ, 2011. $20 \mathrm{c}$.

11. Арістова І.В., Кузнецова М.Ю. Реалізація інформаційно-правового статусу органів виконавчої влади України в інформаційних правовідносинах: 
монографія / За заг. ред. І.В. Арістової. Київ : Видавничий центр НУБіП України, 2015. $250 \mathrm{c}$.

12. Арістова I.В., Чернадчук В.Д. Концепція інформаційних правовідносин: сутність та особливості використання у сфері банківської діяльності. URL : https://goo.gl/6ZPyTf (дата звернення: 19.10.2020).

13. Арістова I.В., Ткаченко В.В. Інформаційне законодавство України: проблеми адаптації до міжнародних правових стандартів : монографія / За заг. ред. І.В. Арістової. Київ : Видавничий центр НУБіП України, 2015. 185 с.

14. Чернадчук Т.О. Актуальні питання інформаційних правовідносин у банківській сфері : монографія / За заг. ред. І.В. Арістової. Суми : Вид-во CHAУ, 2011. $162 \mathrm{c}$.

15. Арістова I.B., Стадник P.I. Органи виконавчої влади України як розпорядники публічної інформації: теоретико-правові та практичні питання : монографія / За заг. ред. І.В. Арістової. Київ : Видавничий центр НУБіП України 2018. $233 \mathrm{c}$.

16. Aristova I.V. Kaliuzhna S.V. Legal status of the public authorities of Ukraine under European integration and the information society development. Innovative scientific research: European development trends and regional aspects. Collective monograph. Riga : Izdevniecība «Baltija Publishing», 2020. P. 1. P. 68-86.

17. Арістова І.В., Курило В.І., Крегул І.Ю. Проблеми правового регулювання співробітництва України з міжнародною організацією ЮНЕСКО у сфері правового забезпечення розвитку інформаційного суспільства в Україні : монографія / За заг. ред. І.В. Арістової. Київ : Центр учбової літератури, 2013. $216 \mathrm{c}$.

18. Арістова І.В. Методологічні засади розбудови суспільств знань. Правова інформатика. 2008. № 3(19). С. 10-17.

19. Арістова I.В. Державна інформаційна політика та ії реалізація в діяльності органів внутрішніх справ України: організаційно-правові засади : дис. ... докт. юрид. наук : 12.00.07. Харків : Національний ун-т внутр. справ, 2002. $476 \mathrm{c}$.

20. Сировой О.В. Організаційно-правові засади управління інформаційними ресурсами органів внутрішніх справ України : автореф. дис... канд. юрид. наук : 12.00.07. Харків : Національний ун-т внутр. справ, 2006. 20 с.

21. Арістова I.B., Сулацький Д.В. Інформаційна безпека людини як споживача телекомунікаційних послуг : монографія / За заг. ред. І.В. Арістової. Харків : Право, 2013. 184 с.

22. Макогонюк Ю.Ю. Організаційно-правові засади забезпечення права на доступ до публічної інформації в екологічній сфері України : дис.. ... канд.. юрид. наук : 12.00.07. Київ, 2017. 241 с. 
23. Арістова I.В. Інформаційне суспільство та суспільства знань: порівняльно-правовий аналіз й досвід для України. Українсько-грецький міжнародний науковий юридичний журнал. Порівняльно-правові дослідження. 2008. № 2. C. 27-29.

24. Арістова І.В., Бєлявська С.Ю. Удосконалення судового управління в Україні: організаційно-правові засади впровадження інновацій : монографія / За заг. ред. І.В. Арістової. Київ : НУБіП України, 2016. 194 с.

25. Арістова І.В., Курило В.І., Калугін О.Ю. Впровадження інформаційнокомунікаційних технологій в аграрний сектор економіки України: організаційно-правовий аспект : монографія / За заг. ред. І.В. Арістової. Київ : Редакційно-видавничий центр НУБіП України, 2014. 193 с.

26. Арістова I.В., Курило В.І., Скоромний Я.І. Організаційно-правові засади надання адміністративних послуг у сільському господарстві України : монографія / За заг. ред. І.В. Арістової. Київ : Видавництво центр НУБіП України, 2015. $156 \mathrm{c}$.

27. Арістова І.В., Шульга М.В. Правове регулювання суспільних відносин у межах наукових спеціальностей 12.00 .06 та 12.00.07: методологічний аспект. Актуальні проблеми екологічних, земельних та аграрних правовідносин: методологічні й прикладні аспекти: матеріали круглого столу (м. Харків, 5 грудня 2014 року). Харків : Національний юридичний університет ім. Ярослава Мудрого. 2014. С. 22-25.

28. Арістова I.В. Організаційно-правові механізми ЮНЕСКО щодо розвитку інформаційного суспільства: орієнтир для України. Правова інформатика. 2009. № 1. С. 17-21.

29. Арістова I.В. Розбудова правової держави в Україні: правовий механізм забезпечення права на доступ до інформації в суспільстві знань. Правова інформатика. 2010. № 1. С. 3-13.

Information about the authors: Aristova I. V., Doctor of Law, Professor, Head of the Department of Administrative and Information Law Sumy National Agrarian University 160, Herasym Kondratiev str., Sumy, 40021, Ukraine

Tkachenko V. V., $\mathrm{PhD}$ in Law, Senior Lecturer at the Department of Administrative and Information Law Sumy National Agrarian University 160, Herasym Kondratiev str., Sumy, 40021, Ukraine 